\title{
STUDY ON THE EFFECT OF INSEMINATION TIME ON PREGNANCY RATE OF BANGLADESHI BUFFALO IN INTENSIVE FARMING
}

\author{
M.A. Hamid ${ }^{*}$ \\ School of Agriculture and Rural Development, Bangladesh Open University \\ Gazipur-1705, Bangladesh
}

\begin{abstract}
The study was designed to evaluate the insemination time and pregnancy rate of Bangladeshi buffalo at Lal Teer Livestock Breeding and Research Farm, Bhaluka, Mymensingh, Bangladesh during January 2017 to June 2018. A total of 30 cyclic buffaloes were included in this study. The animals were inseminated under four different times, i.e. inseminated i) between 0-6 hours after seeing first sign of estrous, ii) between 6-12 hours after seeing first sign of estrous, iii) between 12-18 hours after seeing first sign of estrous and v) between 18-24 hours after seeing first sign of estrous. The pregnancies (positive or negative) were confirmed by rectal palpation and transrectal ultrasonography after 60 days of artificial insemination (Al). The total pregnant animals in this study were $40 \%$. The highest pregnancy rate $(60 \%)$ was observed in insemination between 12-18 hours after seeing first sign of estrous and the lowest pregnancy rate $(0 \%)$ was observed in insemination between 0-6 hours after seeing first sign of estrous. The findings of the study suggest that, the conception rate of buffalo depend on the time of $\mathrm{Al}$, detection of proper estrus symptoms and site of semen deposition.
\end{abstract}

Keywords: Bangladesh, buffalo, insemination, pregnancy

\section{INTRODUCTION}

Buffalo is a multipurpose domestic animal has extraordinary capacity utilization of less digestible feeds (straw, sugar cane wastes, crop residues etc.) helps the livelihood of people by providing excellent quality food milk and meat. Buffaloes are economically and culturally important livestock species especially in developing countries (Hagos and Mokhtar, 2015). It plays a significant role through contributions in social and cultural aspects (Desta, 2012). Buffalo milk can be converted into many kinds of cheese, primarily mozzarella (Aspilcueta-Borquis et al., 2012). Furthermore, buffaloes are valuable work animals (Perera, 2008), commonly used as

\footnotetext{
*Corresponding author email: hamidethu@yahoo.com,drmahamid.bou@ gmail.com
} 
draught animals in crop fields. The water buffalo is the second most important species in the world in terms of milk production, after dairy cows (Coroian et al., 2013) and good source of milk and meat in all over the world. Comparing to cow, buffalo milk is higher in protein, fat, lactose and energy.

India is the highest buffalo populated country in the world comprising 112.91 million buffalo (58.11\% of the world). India is the world's topmost milk producing country in the world where buffalo forms the backbone of India's dairy industry which share $67.99 \%$ of world's buffalo milk production (Chakravarty, 2013). Pakistan is the second most buffalo populated country in the world, contributes $16.83 \%$ of world buffalo population (FAO, 2012). The famous Pakistani breeds are Nili, Ravi, NiliRavi, Kundi etc. (Khan, 2001). Pakistan is the $2^{\text {nd }}$ largest buffalo milk producing country in the world, contributes $23.96 \%$ of total buffalo milk production.

Bangladesh is a south Asian country where the economy is based primarily on agriculture, and livestock is an essential component of the rural economy. The buffalo is an important part of livestock in Bangladesh. The total buffalo population of the country is 1.457 million (DLS, 2015) of which coastal regions posses about 40\% (Faruque et al., 1990). Most of the populations are reverine type with the exception of some swamp type found in Bangladesh. In Bangladesh, buffalo used primarily for draught purpose or dairy and meat production is a secondary option. There is no recognized breed of water buffaloes in Bangladesh and are mainly indigenous non descriptive types. Though total milk production of Bangladesh is about $6.09 \mathrm{MT}$ in 2014 out of which about 3 to $4 \%$ is produced by the buffalo in spite of the number buffalo growth rate are increasing during last 10 years (DLS, 2015). The consumption of milk and meat was increased by @ 4.0\% and 12.7\% during 2005 to 2010 . At the same time, rice consumption was decreased by $5.0 \%$. Presently, it is increasing the number of consumer of buffalo milk because of its white color, high fat content and flavor. As a result there is a high demand for buffalo milk in the country, but milk yield per dairy buffalo is very low which is 600-1000 liter per 250270 days lactation period (Faruque et al., 1990). This indicates that Bangladesh have great opportunity to produce buffalo milk because of its high consumer preference and demand. However, the sector is not poetically utilized yet due to many constraints. In Bangladesh, buffalo has never been addressed and always neglected species despite their important role in the national economy (Huque and Borghese, 2012).

According to the national health strategy, an adult people need $250 \mathrm{ml}$ milk and 120 gm of meat every day. However, presently the availability is only $43.44 \%$ and $67.17 \%$, respectively (DLS, 2015). Under these circumstances, to meet up the deficiency of milk and meat, the government and private organizations should put efforts together to enhance the present milk and meat production status. Recently, the demand for animal derived products such as milk, meat, butter, cheese, ice-cream, baby foods, locally made sweets are increasing which are heavily dependent on milk plus sugar. 
It is known by all buffalo is a silent heat animal and not showing promt heat symptoms as like cattle and if the farmer/owner is not suited/familiar to identify them, then it arises problems. Undetected heat result longer calving intervals, lower lifetime milk production and fewer calves. In buffalo, usually/normally, the onset of heat/estrus is midnight (12.0 am to $1.0 \mathrm{am}$ ) and it lasts for 18-20 hours but sometimes to 36 hours. The animal owners and/or the inseminators should inseminate the buffalo in the right time for higher conception rates following proper heat detection technique. Usually, good fertility can be obtained inseminate between 6-18 hours after ovulation. The detection of oestrus has been very important for the buffalo herd's profitability. By an early and correct detection of oestrus (heat), artificial insemination has been carried out at the right time.

The time of insemination is very important to obtained maximum fertility and conception. Consequently, to know proper heat detection technique and accurate breeding time has been becoming more important to help the farmer to profitable buffalo farming. Therefore, the present studies was undertaken to investigate the accurate breeding time to improve conception and pregnancy rate of buffalo and to improve the livelihood of farmers and ensure high level of food security through buffalo production

\section{MATERIALS AND METHODS}

\section{Location and climatic conditions}

This research was conducted at Lal Teer Livestock Breeding and Research Farm (LTL) which is located at Bhaluka of Mymensingh district in Bangladesh. The farm is situated between $24^{\circ} 01^{\prime}$ and $24^{\circ} 47^{\prime}$ North latitude and between $89^{\circ} 15^{\prime}$ and $89^{\circ}$ $49^{\prime}$ East longitude. The temperature is moderate to high throughout the year with only slight variation between seasons and ranging between $12^{\circ} \mathrm{C}$ and $35^{\circ} \mathrm{C}$. Summer begins in mid-April and lasts up to mid-June. Winter normally lasts from December to late February. The monsoon (rainy) season commences towards the end of June and continues to September. The level of rainfall is highest during monsoon and the lowest in March.

\section{Experimental animals}

Domestic indigenous buffalo of Bangladesh belongs to the Bubalus bubalis with most of the population are reverine type with exception of some swamp type found in eastern part and crossed or wild Arni type (Bubalus arnee) found in southern coastal areas (Faruque et al., 1990; Huque and Borghese, 2012). The LTL has a total of 35 breeding buffalo available excluding breeding bulls, calves and heifers. The present study was conducted a total of 30 cyclic buffalo which was Indigenous Murrah type, Plain land Riverine type and wild Arni/Crossed type. 
The Indigenous Murrah type is mainly dual type and is distributed in western part and different from other breeds. Their coat color is usually black and the horns are short, tight, turning backward and upward and finally spirally curving inward. The body sound built, heavy and wedge shaped. The cows are good sized and possess better milking ability. Males are bigger in size than female. The Plain land Riverine type is also dual type and mainly found in the sandy islands of the river Brahmaputra and the Jamuna of the central part of the country. The coat color is usually black and horns are medium in size and curving inward. Body sound built, medium and wedge shaped. The wild Arni type is gray to black in color with off-white "socks" and one or two white chevrons on the neck. The horns curve backward in a crescent.

The photograph of Indigenous Murrah, Plain land Reverine and Wild Arni is presented in Photo 1, 2 and 3 respectively.

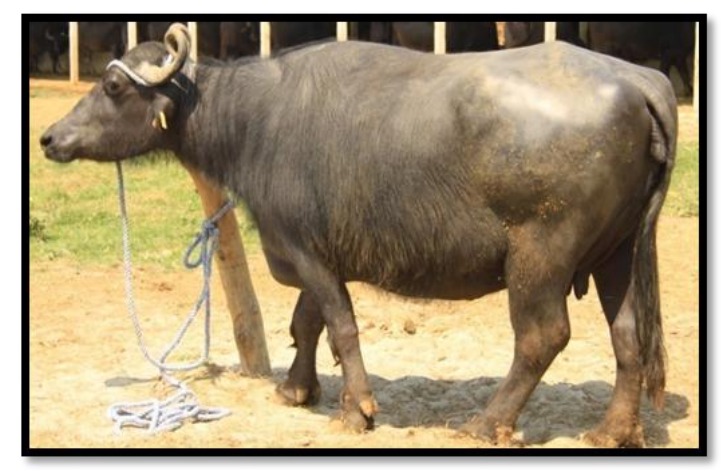

Photo 1. Photograph of Indigenous Murrah Buffalo

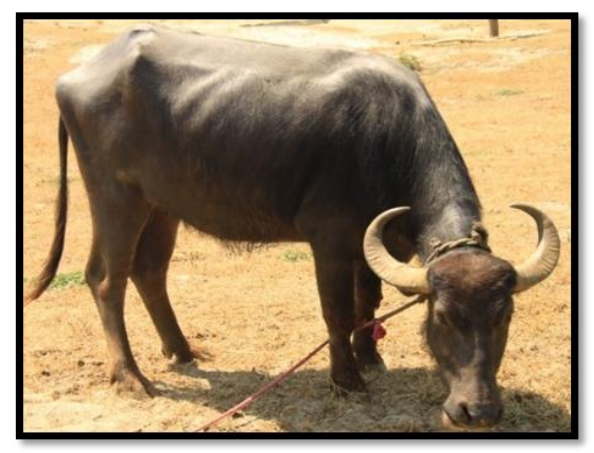

Photo 2. Photograph of Plain land Riverine Buffalo 


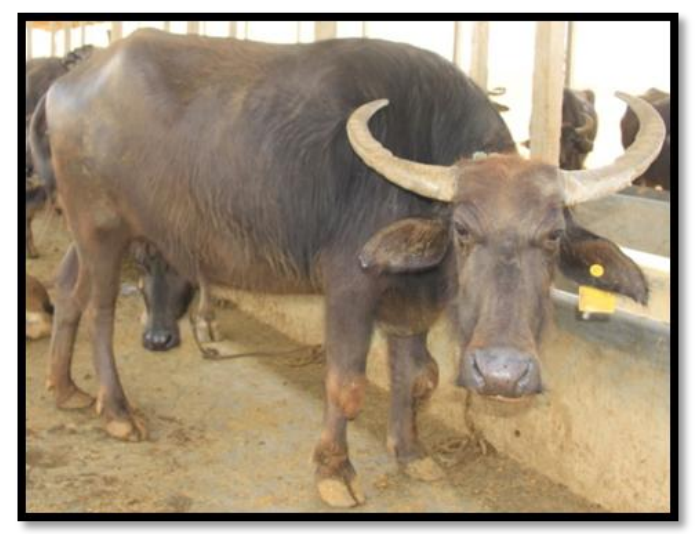

Photo 3. Photograph of wild Arni Buffalo

\section{Herd Management}

The animals were managed intensively in pens with sufficient cross-ventilation and protected from hot-sun and heavy rainfall to avoid abrupt fluctuation of their body temperature during the whole period. Each buffalo (maintenance + pregnant) was fed with a total of $1.04 \mathrm{~kg}$ concentrate mixture containing $0.25 \mathrm{~kg}$ broken maize, $0.17 \mathrm{~kg}$ wheat bran, $0.30 \mathrm{~kg}$ mustard oil cake, $0.12 \mathrm{~kg}$ rice polish, $0.11 \mathrm{~kg}$ molasses, $0.01 \mathrm{~kg}$ vit-min. premix, $0.01 \mathrm{~kg}$ di-calcium phosphate, $0.02 \mathrm{~kg}$ oyster shell, $0.05 \mathrm{~kg}$ iodine salt, (15.0\% crude protein, $74.0 \%$ TDN, $2.48 \mathrm{Mcal} \mathrm{ME);2.0} \mathrm{kg} \mathrm{straw} \mathrm{and} \mathrm{8-10} \mathrm{kg}$ green grass per day. The dry and early pregnant animals were allowed to graze 2-3 hours/day. Most commonly available green fodders were Napier, Sorghum, Maize, and Berseem. Fresh drinking water was provided ad libitum. Routine veterinary attention was provided to each animal. No buffalo was affected with remarkable diseases. The buffalos were regarded as clinically healthy and free from any significant abnormalities. They were vaccinated routinely against Foot and mouth disease (FMD), Anthrax, Hemorrhagic Septicemia (HS) and Black Quarter (BQ). Buffalos were dewormed with a combined preparation of Tetramisole Hydrochloride and Oxyclosanide (Levanid $^{(\mathrm{R})}$, The ACME Laboratories Ltd, Dhaka, Bangladesh) twice in a year. To control external parasites, the farm areas were sprayed once a week with broad spectrum disinfectant.

\section{Experimental design}

This research was done at LTL during the period of January 2017 to June 2018 with the assistance of some technical persons and farm workers of this farm. Heat detection was based on visual observations, performed three times a day (morning 06.00, midday 12.00 and afternoon 15.00), involving 20 minutes of watching reports from the high skilled research assistant and trained farm workers. In addition, we followed the estrus cycle of calving buffalo, e.g., $1^{\text {st }}$ cycle at the day of $19-23,2^{\text {nd }}$ cycle at the day of 40-44 and $3^{\text {rd }}$ cycle at the day of 61-65 after parturition. During 
these periods, the milked animals were not milking. When an animal was found with different external and internal symptoms of heat, this animal was considered to be in oestrus. All of the symptoms were captured with Sony Handycam and stored on hard drives to use them when necessary. All of the symptoms have been followed by research assistant and farm workers to prevent bias.

In this research, we inseminated the animals under four different times, i.e. inseminated i) between 0-6 hours after seeing first sign of estrous, ii) between 6-12 hours after seeing first sign of estrous, iii) between 12-18 hours after seeing first sign of estrous and v) between 18-24 hours after seeing first sign of estrous at LTL farm. Pregnancies (positive or negative) were confirmed by rectal palpation on day 60 post A.I. by a trained veterinarian; and repeat breeders were inseminated accordingly.

\section{Control}

Each day around noon the animals which had been registered to be in oestrus by at least one of the four methods in the previous 24 hours were checked to make sure there were no false positives.

This was done by gynaecological examination with an ultrasound to determine if there was either a corpus luteum $(\mathrm{CL})$ or follicle $(>10 \mathrm{~mm})$ present in the ovaries, but also if there was a tonus of uterus and outflow of mucus. If there was a CL present there can be no oestrus at the same moment (false positive). If there was no CL but a follicle present $(>10 \mathrm{~mm}$ ) the animal was considered to be in oestrus (true positive).

\section{RESULTS AND DISCUSSION}

For accurate breeding time, we inseminated (artificially) a total of 30 cyclic buffaloes under four different times and observed final conception (positive or negative) following pregnancy diagnosis. After confirmation of proper heat, we inseminated the selected buffalo artificially by trained and skilled inseminator. After 60 days of insemination, we confirmed pregnant buffalo by rectal palpation with skilled veterinarian. The photograph of Indigenous Murrah, Plain land Reverine and Wild Arni is presented in Photo 1, 2 and 3 respectively. The picture for preparation of artificial insemination, the use of hormone in artificial insemination, the artificial insemination in heated buffalo, the pregnancy diagnosis by rectal palpation and the pregnancy diagnosis with ultrasonography is presented in Photo 4, 5, 6 and 7 respectively. 


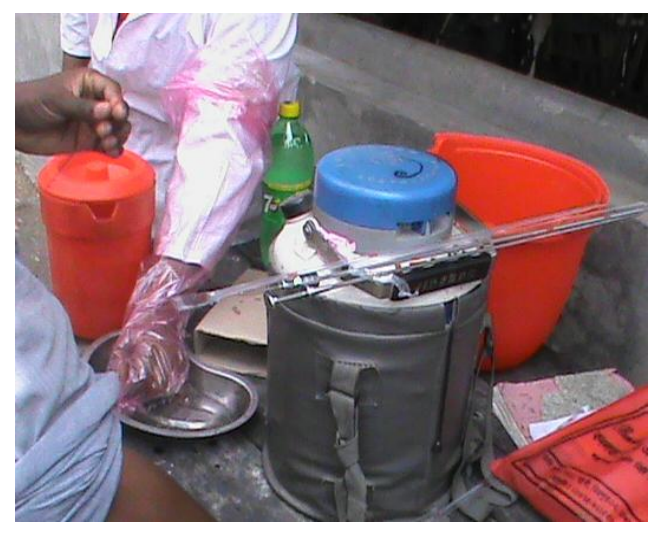

Photo 4. Preparation for artificial insemination

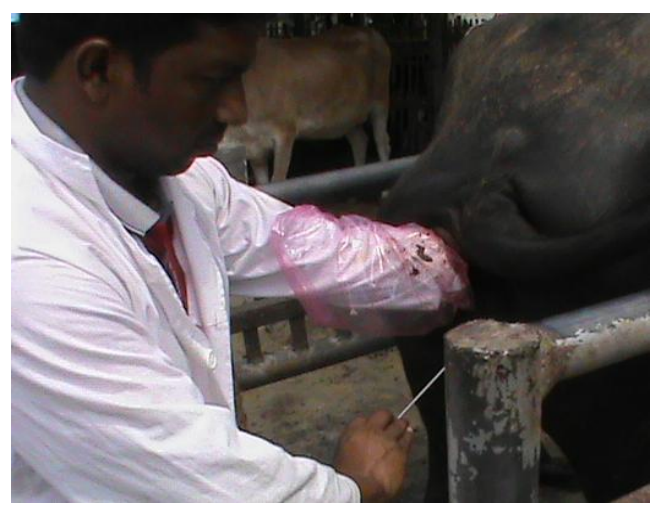

Photo 5. Artificial insemination (heated buffalo)

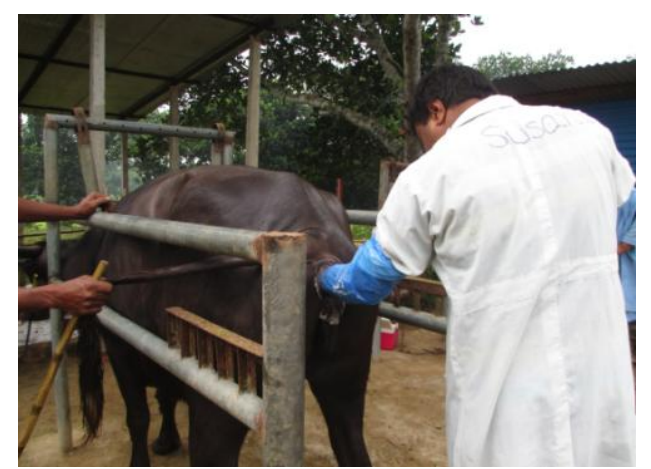

Photo 6. Pregnancy diagnosis by rectal palpation 


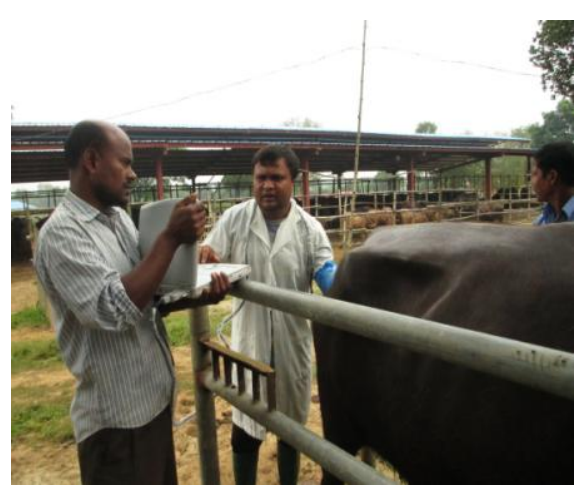

Photo 7. Pregnancy diagnosis with ultrasonography

We confirmed that the percentage of total pregnant animals was $40 \%$ (Table 1). The results for percentage of pregnant animals at insemination between 0-6 hours after seeing first sign of estrous was $0 \%(0 / 5)$, insemination between 6-12 hours after seeing first sign of estrous was 50\% (5/10), insemination between 12-18 hours after seeing first sign of estrous was 60\% (6/10) and insemination between 18-24 hours after seeing first sign of estrous was $10 \%$ (1/5) respectively. The differences of conception and pregnancy rate between inseminating times may be proper estrus of buffalo, time of A.I., site of semen deposition.

Table 1. No. of pregnant buffalo with insemination at different times

\begin{tabular}{c|c|c|c|c}
\hline Sr. & \multicolumn{1}{c|}{ A.I. time } & $\begin{array}{c}\text { No. of } \\
\text { Animal }\end{array}$ & $\begin{array}{c}\text { Pregnant } \\
\text { animal }\end{array}$ & $\begin{array}{c}\% \text { of } \\
\text { pregnancy }\end{array}$ \\
\hline $1 \quad \begin{array}{l}\text { inseminate between 0-6 hours after } \\
\text { ovulation } \\
\text { inseminate between 6-12 hours after } \\
\text { ovulation }\end{array}$ & 5 & 0 & $0 \%$ \\
$3 \quad \begin{array}{l}\text { inseminate between 12-18 hours after } \\
\text { ovulation } \\
\text { inseminate between 18-24 hours after } \\
\text { ovulation }\end{array}$ & 10 & 5 & $50 \%$ \\
$\quad$ Total & 30 & 12 & $60 \%$ \\
\hline
\end{tabular}

Source: Based on research report

In the review, we found that a number of controlled or breeding programs have been developed for synchronizing groups of lactating cattle/buffalo. Controlled breeding can be directed to cows that pass a corpus luteum test as determined by rectal 
palpation of the ovaries and for further administering PGF2 $\alpha$ to these animals. It was observed that all the cows and buffaloes were in heat after 16-24 hrs in $2^{\text {nd }}$ dose of Receptal injection. It has been observed that cows in early and late stages of the cycle tend to exhibit heat within $48-72 \mathrm{~h}$ after receptal administration.

The spermatozoa need some time in the female reproductive tract to undergo for maturation (capacitation). The life of the ovum in the fallopian tube is short and ovulation occurs approximately 28-32 hours from the time of onset of estrus. Good fertility can be obtained between 6-12 hours after ovulation or nearer to the end of mid heat. Therefore the best time is to inseminate in the evening if the estrus is observed in the morning and if observed in the evening the insemination should be done the next day morning. In buffaloes the estrus period is long when compared to cattle. It will be 24-36 hours. Therefore insemination in buffaloes should be done in about 24 hours after the onset of heat. Therefore if the buffalo comes to heat in the morning insemination should be done next day morning. Similarly if it comes to heat in the evening insemination should be done next day evening.

Dalton et al., 2001 conducted an experiment to determine the effect of insemination time on fertilization status and embryo quality in single-ovulating cows. All cows were continuously monitored by Heat Watch and received AI with one $0.5-\mathrm{mL}$ straw $\left(25 \times 10^{6}\right.$ sperm) of semen from one of three bulls at 0,12 , or $24 \mathrm{~h}$ after the onset of standing heat. He found that, fertilization rates were greatest in embryos recovered following the 24-h AI treatment.

In various management schemes, it is unrealistic to expect heat detection and AI to occur more than once daily. In this management strategy AI should occur as soon after detection as possible, as the short lifespan of the ovum must be considered the limiting factor. Heat detection and AI studies, however, have reported similar fertility results for once-daily AI and AI following the A.M.-P.M. guideline (Foote, 1978; Nebel et al., 1994).

\section{CONCLUSION}

In this study, the animals were inseminated under four different times. Pregnancies (positive or negative) were confirmed by rectal palpation on day 60 post AI by a trained veterinarian; and repeat breeders were inseminated accordingly. The total pregnant animals were found $40 \%$. The highest pregnancy rate $(60 \%)$ was observed in insemination between 12-18 hours after seeing first sign of estrous and the lowest pregnancy rate $(0 \%)$ was observed in insemination between $0-6$ hours after seeing first sign of estrous. It is concluded that, appropriate semen storage, semen handling, and site of semen deposition in the female reproductive tract are critical factors related to achieving a successful breeding program. 


\section{REFERENCES}

Aspilcueta-Borquis, R.R., Neto F.R.A., Baldi F., Santos D.J.A., Albuquerque, L.G., and Tonhati H. (2012). Genetic parameters for test-day yield of milk, fat and protein in buffaloes estimated by random regression models. J. Dairy Res., 79: 272-279.

Chakravarty, A.K. (2013). Strategies for genetic improvement of buffaloes through production of quality male germplasm in SAARC countries. Seminar Paper Presentation in High Yielding Dairy Buffalo Breed.

Coroian, A., Erler, S., Matea, C.T., Mireșan, V., Răducu, C., Bele, C., and Coroian, C.O.. (2013). Seasonal changes of buffalo colostrum: physicochemical parameters, fatty acids and cholesterol variation. Chemistry Central Journal 7(1): 40.

Dalton, J.C., Nadir, S., Bame, J.H., Noftsinger, M., Nebel, R.L., and Saacke R.G. (2001). Effect of time of insemination on number of accessory sperm, fertilization rate, and embryo quality in nonlactating dairy cattle. J. Dairy Sci. 84:2413-2418.

Desta T.T. (2012). Introduction of domestic buffalo $(<i>$ Bubalus bubalis $</ i>)$ into Ethiopia would be feasible. Renewable Agric. Food Syst., 27: 305-313.

DLS. (2015). Annual report on livestock. Division of Livestock Statistics, Ministry of Fisheries and Livestock, Farmgate, Dhaka, Bangladesh.

FAO. (2012). The state of food and agriculture, (2012). Food and Agriculture Organization of the United Nations, Rome. http://www.fao.org/docrep/017/i3028e/i3028e.pdf.

Faruque, M.O., Hasnath, M.A., and Siddique, N.U. (1990). Present status of buffaloes and their productivity. Asia-Australian J. Anim Sci.3: 287-292.

Foote, R.H. (1978). Time of artificial insemination and fertility in dairy cattle. J. Dairy Sci. 62:355-358.

Hagos A., and Mokhtar K. (2015). A review on strategies for sustainable buffalo milk production in Egypt. J. Biol. Agric. Healthcare, 5: 63-67.

Huque, Q.M.E., and Borghese, A. (2012). Production potentiality and perspective of buffalo in Bangladesh. Procedings of the 15th AAAP Animal Science Congress, November 26-30, 2012, Thailand, pp: 244.

Khan, S. (2001). Water buffaloes for food security and sustainable rural development in Pakistan. Proceedings of the Regional Workshop on Water Buffalo Development, (WBF'01), Surin, Thailand, pp: 77-83.

Nebel, R.L. (2003). Components of a successful heat detection program. Adv. Dairy Technol. 15:191-203.

Perera, B. (2008). Reproduction in domestic buffalo. Reproduction in Domestic Animals. 43: 200-206. 